\title{
BOSCHI, Caio César. Por que estudar História? São Paulo: Ática, 2007.
}

\author{
Mário Cléber Martins Lanna Júnior*
}

Por que não estudar história? Essa é a pergunta que fica, em tom de espanto e provocação, depois da leitura do livro Por que estudar História?. Uma reflexão sobre os motivos que justificam e instigam o estudo dessa disciplina, o livro é voltado para o público jovem, do nível básico, de escolas secundárias e superiores. Foi para esse público específico que se dirigiu o professor e historiador Caio César Boschi, autor conhecido por seus trabalhos sobre as irmandades religiosas em Minas Gerais, no período colonial. O livro trata de assuntos complexos e fundamentais da história, de forma simples e acessível a qualquer público interessado, que pretende aventurar-se nos primeiros passos sobre o conhecimento histórico. O texto discorre sobre temas adequados aos tratados de metodologia e teoria da história, com clareza e segurança. O resultado é uma síntese de fácil compreensão, sem superficialidades e omissões.

Para que serve a história? O que faz o historiador? Por que é importante aprender história? Essas perguntas aparecem no subtítulo do livro e são respondidas por uma perspectiva teórica inspirada em Marc Bloch, Fernand Braudel, Marc Ferro, Jacques Le Goff, Pierre Nora, Philippe Ariès, Eric Hobsbawn e Josep Fontana, historiadores que o texto referenda, além de literatos como Leon Tolstoi, Bertold Brecht e Carlos Drummond de Andrade, apenas para citar alguns nomes. Essas referências apontam para uma historiografia inspirada na Escola dos Annales e no marxismo, influências que sustentam a definição de história do autor, sem cair no modismo ou no senso comum.

Caio César Boschi defende que o conhecimento histórico é vivo e sempre atual. O historiador atira no passado, mas seu alvo é o presente, ou melhor, o homem no tempo. $\mathrm{O}$ homem é o sujeito e simultaneamente o objeto desse conhecimento. A história, ao refletir sobre nossas experiências passadas, contribui para compreendermos o nosso presente, o que fomos e quem somos hoje, além de apontar possibilidades e escolhas para o futuro. A

\footnotetext{
* Doutor em história pela Universidade Federal do Rio de Janeiro (UFRJ). Professor do Curso de História da PUC Minas, pesquisador do Centro de Memória e Pesquisa Histórica PUC Minas e pesquisador licenciado da Fundação João Pinheiro.
} 
história vai muito além do conhecimento do passado, ela oferece uma visão abrangente da vida em sociedade e dos homens que a integram e a transformam.

O perigo é o "fascínio do passado", segundo o autor, ou a "naturalização da história”, quando transformamos a história em um conhecimento acrítico. Esse equívoco anula a principal razão da história, de ser um instrumento de mudança, produtora de um conhecimento presente e prospectivo, de entender o homem em sua dimensão temporal. A história estuda o passado com o objetivo de trazer luzes para os problemas atuais. Como um instrumento de ação no presente, serve para transformar-nos em agentes de mudanças do processo histórico. Ela liberta ou confirma a servidão, pois a razão fundamental do conhecimento histórico é desvelar como agentes ou setores da sociedade se apropriam do poder e o utilizam para manter privilégios próprios.

A exaltação do passado dificulta a consciência do presente, como nas "historias heróicas". No sentido oposto, para Caio Boschi, os estudos sobre mitos e memórias, do ponto de vista dos movimentos coletivos dos homens, constituem ocasiões privilegiadas para identificarmos os elementos do passado que podem auxiliar na compreensão do presente e na construção do futuro. O mito e a memória são fontes informativas da história através dos quais se pode explicar como as identidades são construídas conforme a consciência histórica de cada sociedade. Esse é um passo importante na formação e no aprimoramento da consciência universal sobre os direitos dos homens. $\mathrm{O}$ historiador deve saber que os mitos e as memórias são formas de adaptações do passado no presente, diferentemente da história, que é um estudo em evidências documentadas.

Os fatos passados são comumente relacionados à história. Eles orientam o conhecimento histórico sem ser a história que, como lembra o autor, está longe de ser um banco de dados de acontecimentos passados. Caso contrário, a história seria um conhecimento estagnado. Afinal, o fato, em sua existência pura e real, é inquestionável, mas a interpretação dada ao fato modifica-se a cada época. Por isso, a história está sempre em transformação, na medida em que o presente atribui novos valores aos fatos passados. O conhecimento vivo constitui-se na mola mestra da história e, dentro dessa visão, fala-se em um estudo do passado com o olhar do presente. Isso explica como surgem os temas, objetos e interesses da história, inspirados em questões do presente. Explica, também, porque a história é um conhecimento inacabado, feito de versões em constante processo de revisão, provocadas pelos problemas, descobertas, fontes e fatos surgidos no presente. 
O fato de estar sempre em construção não deve ser usado para justificar julgamentos e relativismos na história. O historiador opina e participa das questões de seu presente e reconhece que seu conhecimento não é a realidade crua, mas representa uma interpretação possível e lógica dessa realidade. Se o historiador julga e condena as escolhas e ações do passado, ele desvirtua e corrompe o conhecimento histórico. O mesmo acontece quando qualquer afirmação é dita como verdade. O conhecimento histórico não é relativo, nem equivale a um conjunto de interpretações onde há espaço para todas as versões. A história busca construir seu conhecimento com base em elementos concretos, informações e testemunhos que chegam até o historiador através das fontes históricas.

Caio Boschi salienta a diversidade das fontes históricas usadas pelo historiador de hoje, um rico e diferenciado material que pode estar guardado em arquivos públicos e privados, inventários, censos, cartas, iconografias, jornais, entre outros, além de relatos orais e de bens patrimoniais culturais, materiais e imateriais, como edificações, logradouros, espaços públicos, obras de arte, literatura, músicas e festas populares. O importante é considerar que, como os fatos passados, as fontes históricas também não são a história. As fontes falam e informam de acordo com as perguntas que o historiador faz. Sem um problema as fontes ficam mudas e não há história, além do que várias perguntas podem ser feitas para uma mesma fonte, o que a torna um instrumento inesgotável de pesquisa.

Sem um problema, por conseguinte, não há história. O historiador irá estudar esse problema pela perspectiva do tempo, o qual não configura um conceito uniforme, muito menos tem valor universal. O calendário e o tempo que esse instrumento marca existem por acordo, são, ambos, calendário e tempo, convenções dos homens em sociedade. Existem duas noções de tempo: o tempo histórico e o tempo cronológico, da natureza. Ambos são relativos e apresentam várias dimensões. Para percebermos o tempo é necessário haver mudanças. Portanto, o tempo é a percepção das semelhanças e diferenças, das permanências e transformações. Caio Boschi ensina que o tempo é um instrumento para o historiador medir a mudança, serve para ordenar a história, colocar os acontecimentos em ordem cronológica. Da mesma forma, a periodização é uma ferramenta prática do historiador para oferecer uma compreensão da totalidade, estabelecer como os fatos se articulam, como as permanências e rupturas caracterizam uma determinada época. Como é construída pelo próprio historiador, toda periodização é sempre subjetiva. 
Caio Boschi explica o que é história e sua relação com cultura, multicultura, tolerância, poder, progresso, memória, lembranças, etnocentrismo, identidade, alteridade, mitos, heróis, memória, lembranças, tempo, historicidade, pesquisa, interdisciplinaridade, investigação, documentos, veracidade etc. Assuntos indicadores da riqueza do conteúdo do livro, uma resposta para o Por que estudar História?. Um texto oportuno para os iniciantes dos estudos históricos e instigante para os historiadores iniciados, que ganham a oportunidade de relerem assuntos fundadores da história, tratados com seriedade e simplicidade. 